\title{
Influence of crop load on the yield and grape quality of Merlot and Vranac (Vitis vinifera L.) varieties in Trebinje vineyard
}

\author{
Mersija DELIĆ ${ }^{1}$, Fikreta BEHMEN ${ }^{2}$, Saša MATIJAŠEVIĆ ${ }^{3}$, Šaćira MANDAL ${ }^{4}$, Saud HAMIDOVIĆ ${ }^{2}$, \\ Senad MURTIĆ 5,6
}

Received April 08, 2020; accepted October 30, 2021. Delo je prispelo 8. aprila 2020, sprejeto 30. oktobra 2021

\begin{abstract}
Influence of crop load on the yield and grape quality of Merlot and Vranac (Vitis vinifera L.) varieties in Trebinje vineyard

Abstract: The aim of this study was to study the impact of crop load on the yield and grape quality of 'Merlot' and 'Vranac' (Vitis vinifera L.) in Trebinje vineyard. The crop load levels studied in this trial were 9 buds (V1) and 12 buds (V2) per vine at each variety trained on Lenz-Moser bilateral cordon system. The impact was determined by measurements of yield per vine and grape quality characterized by the contents of total soluble solids, titratable acidity, total phenolics, total flavonoids and by total antioxidant capacity. The measured parameters of grape quality of 'Merlot' and 'Vranac' were not influenced significantly by crop load levels. V2, compared to the V1, showed the potential for increasing grape yield only for Merlot variety under experimental conditions. The results of this study also showed a positive correlation between total phenolics/flavonoids and total antioxidant capacity of grape berries in both varieties, regardless of crop loads applied.
\end{abstract}

Key words: flavonoids; total phenolics; pruning; yield
Vpliv obtežitve na pridelek in kakovost grozdja sort Merlot in Vranac (Vitis vinifera L.) v vinogradu v Trebinju

Izvleček: Namen raziskave je bil preučiti vpliv obtežitve trt na pridelek in kakovost sort Merlot in Vranac (Vitis vinifera L.) v vinogradih Trebinja. Velikost obremenitve trt v tem poskusu so bile trte z 9 (V1) in 12 brsti (V2) na vsako sorto, gojeno na Lenz-Moser bilateralnem kordonu. Vpliv je bil določen $\mathrm{z}$ meritvami pridelka na trto, kakovost grozdja je bila določena z vsebnostjo celokupne suhe snovi, titrabilne kislosti, vsebnosti celokupnih fenolov in flavonoidov in celokupne antioksidacijske sposobnosti. Izmerjeni parametri kakovosti grozdja sort Merlot in Vranac niso bili znalično vplivani z obremenitvijo trt. V2 je v primerjavi z V1 pokazala zmožnost povečanja pridelka grozdja samo pri sorti Merlot v razmerah te raziskave. Rezultati te raziskave so pokazali še pozitivno korelacijo med vsebnostjo celokupnih fenolov/flavonoidov in celokupno antioksidacijsko kapaciteto grozdnih jagod pri obeh sortah ne glede na obremenitev trt. lek

\footnotetext{
1 University of Sarajevo, Faculty of Agriculture and Food Sciences, Department of Viticulture, Sarajevo, Bosnia and Herzegovina

2 University of Sarajevo, Faculty of Agriculture and Food Sciences, Department of Horticulture, Sarajevo, Bosnia and Herzegovina

3 University of Belgrade, Faculty of Agriculture, Department of Viticulture, Belgrade, Serbia

4 University of Sarajevo, Faculty of Pharmacy, Department of Natural Sciences in Pharmacy, Sarajevo, Bosnia and Herzegovina

5 University of Sarajevo, Faculty of Agriculture and Food Sciences, Department of Plant Physiology, Sarajevo, Bosnia and Herzegovina

6 Corresponding author, e-mail: murticsenad@hotmail.com
} 


\section{INTRODUCTION}

The grape yield and quality are influenced by many factors such as climatic conditions, soil chemical and physical properties variety, viticulture management practices, crop load, leaf removal, irrigation, and rootstock-scion relationship (Pachnowska and Ochmian, 2018). Among the factors affecting vine growth and development, winter pruning has the greatest impact on the grape yield and quality of the growing season due to its impact on bud fertility and nutrient reserves in grapevine (Qiu et al., 2019). Winter pruning refers to the removal of non-beneficial plant parts during the late dormant season, and retaining only selected buds for the next season's fruiting. In some wine regions, such as France, the exact number of buds for each variety is outlined by the France's Appellation d'Origine Contrôlée regulations (Gangjee, 2012). However, if to many buds are left at winter pruning, the vine will produce many shoots leading to a dense canopy and opposite, if a few buds left, the shoots may grow too vigorously leading to low yield (Collins et al., 2020). In order to achieve the right balance between vegetative growth and grape production it is essential to determine an optimal crop load for each grapevine variety (Pellegrino et al., 2014). Optimal crop load varies from one variety to another, depending mainly on variety itself, vineyard location, soil type, climatic conditions, etc. (Raj Kumar et al., 2017). Crop loads also impacts chemical grape composition and thus the wine quality. From an economic point of view, grape growers must find the correct balance between quantity, fruit quality and long-term vine health when determining appropriate crop levels on their vines (Čuš, 2004; Schamel and Schubert, 2016). Accordingly, permanent necessity for achieving optimal crop loads is always present, especially in regions where the connections among pruning practices and grape production are poorly understood.

Lenz-Moser bilateral cordon is the most commonly used vine training system for 'Merlot' and 'Vranac' (Vitis vinifera L.) in Trebinje region in Bosnia and Herzegovina. Crop load levels commonly used within this training system in Trebinje region are 9 and 12 buds per vine. The effect of crop load treatments on yield of 'Merlot' and 'Vranac' has been extensively investigated. Bogičević et al. (2015) examined the effect of early leaf removal and cluster thinning treatments on berry growth and grape composition of Vranac variety. Results showed that early leaf removal followed by cluster thinning resulted in a lower berry mass and number of berries per cluster, and thus a lower yield. Peppi et al. (2017) noted that an adjustment in mechanical pruning with regard to cutting height is a feasible alternative to obtain regular and sustainable yields in 'Merlot' with considerably lower labour inputs in the vineyard. On the other hand, the effect of crop load treatments on the content of bioactive compounds such as total phenolics and flavonoids in berries of Merlot and Vranac varieties has been less studied.

Therefore, this study is primarily intended to evaluate the impact of crop load on total phenolics, total flavonoids and total antioxidant capacity of grapevine varieties Merlot and Vranac in Trebinje vineyard. The study also included the measurements of the following grape quality parameters: total soluble solids, titratable acidity as well as yield. The hypotheses tested were: (1) lower crop load can effectively increase total phenolic and flavonoid contents and total antioxidant capacity in berries of Merlot and Vranac varieties as compared to higher crop load; (2) total soluble solids, titratable acidity as well as yield in both varieties Merlot and Vranac will differ depending on the crop loads. Understanding the relationship between the crop loads and the grape production in 'Merlot' and 'Vranac' can provide valuable information for management decisions that need to be made in the vineyard.

\section{MATERIALS AND METHODS}

\subsection{EXPERIMENTAL SITE AND PLANT MATE- RIAL}

This study was conducted during 2018 at a commercial vineyard planted with 'Merlot' and 'Vranac' vines grafted onto Richter 110 rootstock. The vineyard was located in a village Zagradinje $\left(42^{\circ} 38^{\prime} \mathrm{N} 18^{\circ} 14^{\prime} \mathrm{E}\right), 10$ kilometers away from Trebinje (Herzegovina region), in a zone of altered Mediterranean climate. In contrast to the narrow coastal area, Trebinje region is characterized by warmer and drier summers, while winters are more humid. According to Köppen and Geiger, climate in Trebinje region is classified as Csa (hot-summer Mediterranean climate). The average annual temperature in studied area is $14.2{ }^{\circ} \mathrm{C}$, and the precipitations average is 1,338 $\mathrm{mm}$. The rain in Trebinje falls mostly in the winter, with relatively little rain in the summer.

Vineyard was planted in 2008 on a sandy-loam soil, with planting distance of $2.5 \mathrm{~m}$ between rows and $1.0 \mathrm{~m}$ between vines in the row. Training system at both Merlot and Vranac was a Lenz-Moser bilateral cordon system. The crop load treatments applied at the study were as follows: (V1) - 9 buds/vine (spurs with 2-3 buds; 3 spurs/ cordon) and (V2) - 12 buds/vine (spurs with 2-3 buds; 5 spurs/cordon). Each crop load treatment consisted of 4 plots located in two different rows (12 vines each; 48 vines per treatment) with one guard row between treatments. Crop loads used in this study are the most preva- 
lent for Merlot and Vranac in Trebinje vineyards and are therefore selected for this study.

Vranac is an autochthonous grapevine variety of Montenegro. The clusters are medium in size (cluster mass is in the range of 180 to $220 \mathrm{~g}$ ) and are well filled with large, thin-skinned berries. The wine of this variety has a pleasant taste, velvety sweetness and intensive dark red colour (Šuković et al., 2020). Merlot is a red grapevine variety from Bordeaux, France. It produces medium to large clusters (cluster mass is in the range of 220 to 300 g) with berries medium large in size and round with blue colour. The Merlot wine is velvety-red, fruity and pleasant taste and very refreshing (Renouf et al., 2010).

\subsection{GRAPE YIELD AND QUALITY ANALYSIS}

Grape yield was weighted at harvest and expressed as $\mathrm{kg}$ per vine. Total soluble solids (TSS) were measured using an Atago PAL-1 digital refractometer and expressed in degrees Brix (ISO, 2003). Titratable acidity (TA) was measured by titrating $10 \mathrm{ml}$ of grape juice with $0.1 \mathrm{~mol} \mathrm{l}^{-1} \mathrm{NaOH}$, using phenolphthalein as indicator (AOAC, 2000) and expressed as grams of tartaric acid per litre of grape juice $\left(\mathrm{g} \mathrm{l}^{-1}\right)$.

\subsubsection{Extraction of phenolics from grape berries}

The extraction of phenolic compounds from the fully ripened and matured grape berries was performed using a $30 \%$ aqueous ethanol solution (Canals et al., 2005). Before extraction, a fresh grape berries were oven dried at $50{ }^{\circ} \mathrm{C}$ until constant mass, ground and then sieved to pass a 2 -mm sieve. The average moisture content was 77.8 \% for Vranac and 79.0 \% for Merlot. Detailed extraction procedures were as follows: $1 \mathrm{~g}$ of air-dried grape sample was placed into $100 \mathrm{ml}$ Erlenmeyer flask and mixed with $40 \mathrm{ml} 30 \%$ aqueous ethanol solution. The flask was heated in a water bath at $35-37^{\circ} \mathrm{C}$ for $1 \mathrm{~h}$. After heating, the flask was cool down to room temperature, and then the mixture was filtered through filter paper into $50 \mathrm{ml}$ flask and diluted to the mark with $30 \%$ aqueous ethanol solution. The extract thus obtained was used for the analysis of total phenolic content, total flavonoid content and total antioxidant capacity.

\subsubsection{Total phenolic content}

The total phenolic content (TPC) of the extract was measured by the Folin-Ciocalteu assay (Ough and Amerine, 1988) with slight modifications. The test sam- ple $(0.25 \mathrm{ml}$ of extract) was mixed into $25 \mathrm{ml}$ flask with $15 \mathrm{ml}$ of distilled water and $1.25 \mathrm{ml}$ of Folin Ciocalteu reagent (diluted by distilled water in the ratio 1:2). After $5 \mathrm{~min}, 3.75 \mathrm{ml}$ of saturated sodium carbonate solution $(8 \% \mathrm{w} / \mathrm{v}$ in water) was added. The flask was filled to the mark with a $30 \%$ aqueous ethanol solution and heated in a water bath at $50{ }^{\circ} \mathrm{C}$ for $30 \mathrm{~min}$. After heating, the flask was cool down to room temperature, and the absorbance of blue colour was measured using a UV Spectrophotometer (Amersham, Ultrospec 2100 pro) at 765 $\mathrm{nm}$. TPC was calculated from a standard curve of gallic acid (5 - $500 \mathrm{mg} \mathrm{l}^{-1}$ ) and the results were expressed as $\mathrm{mg}$ of gallic acid equivalent per $100 \mathrm{~g}$ fresh mass (mg GAE $\left.100 \mathrm{~g}^{-1} \mathrm{FM}\right)$.

\subsubsection{Total flavonoid content}

The total flavonoid content (TFC) of the extract was measured by the aluminium chloride colorimetric assay (Zhishen et al., 1999). The test sample ( $1 \mathrm{ml}$ of extract) was mixed into $10 \mathrm{ml}$ flask with $4 \mathrm{ml}$ of distilled water and $0.3 \mathrm{ml} 5 \% \mathrm{NaNO}_{2}$. After $5 \mathrm{~min}, 0.3 \mathrm{ml} 10 \% \mathrm{AlCl}_{3}$ was added. The flask was incubated at room temperature for $6 \mathrm{~min}$, and thereafter $2 \mathrm{ml}$ of $1 \mathrm{~mol} \mathrm{l}^{-1} \mathrm{NaOH}$ was added. The flask was filled to the mark with distilled water and after $15 \mathrm{~min}$ the absorbance of red colour was measured at $510 \mathrm{~nm}$. TFC was calculated from a standard curve of catechin (0-100 $\left.\mathrm{mg} \mathrm{l}^{-1}\right)$ and the results were expressed as mg of catechin equivalent per $100 \mathrm{~g}$ of fresh mass (mg CE $100 \mathrm{~g}^{-1} \mathrm{FM}$ ).

\subsubsection{Total antioxidant capacity}

The total antioxidant capacity (TAC) of the extract was determined by ferric reducing antioxidant power (FRAP) assay (Benzie and Strain, 1996). The test sample ( $80 \mu \mathrm{l}$ of extract), $240 \mu \mathrm{l}$ of distilled water, and 2080 $\mu \mathrm{l}$ of FRAP reagent (reagent was obtained by mixing $0.3 \mathrm{~mol} \mathrm{l}^{-1}$ acetate buffer $(\mathrm{pH}=3.6), 10 \mathrm{mmol} \mathrm{l}^{-1} \mathrm{TPTZ}$ (2,4,6-tripyridyl-s-triazine) and $20 \mathrm{mmol} \mathrm{l}^{-1} \mathrm{FeCl}_{3}$ × 6 $\mathrm{H}_{2} \mathrm{O}$ in ratio $10: 1: 1$ ) were added into $10 \mathrm{ml}$ Erlenmeyer flask and heated in a water bath at $37^{\circ} \mathrm{C}$ for $5 \mathrm{~min}$. After heating, the flask was cool down to room temperature, and the absorbance of blue colour was measured at 595 $\mathrm{nm}$. TAC was calculated from a standard curve of $\mathrm{FeSO}_{4}$ $\mathrm{x} 7 \mathrm{H}_{2} \mathrm{O}\left(0-2 \mathrm{mmol} \mathrm{l}^{-1}\right)$ and the results were expressed as mmol Fe ${ }^{2+}$ per $100 \mathrm{~g}$ fresh mass (mmol Fe $\left.{ }^{2+} 100 \mathrm{~g}^{-1} \mathrm{FM}\right)$. 


\subsection{STATISTICAL ANALYSIS}

All the chemical measurements of TPC, TFC and TAC were conducted in triplicates and the results were expressed as the mean \pm standard deviation. Experimental data were subjected to analysis of variance (ANOVA) using Microsoft Excel 2013 statistical program. In order to interpret the relationships between total TPC / TFC and TAC, Pearson's correlation coefficient analysis were conducted using the Microsoft Excel 2013 software.

\section{RESULTS AND DISCUSSION}

The results of the analysis of yield and grape quality parameters of 'Merlot' and 'Vranac', depending on crop load treatments are presented in Table 1 and Table 2, respectively.

The results of this study showed that the yield of the Vranac variety in the crop load treatment with nine buds/ vine was significantly lower compared with the higher crop load treatment (twelve buds/vine). This result is expected, since the lower crop load reduces the number of fruitful buds and consequently the number of grape clusters per vine, and thus the yield (Rubio and Yuste, 2002). Interestingly, this hypothesis for the 'Merlot' has not been confirmed in this study. The probably reason for that is less sensitivity of the 'Merlot' to differences in the number of buds in relation to the 'Vranac'. Contrarily, a higher crop load levels allows the vine to produce many grape clusters, which often results in a higher yield (Aipperspach et al., 2020). However, if to many buds left, then vine may produce many shoots that are outwardly observable as a large, leafy canopy leading to poor fruit quality and a weakening of the vine (Keller, 2010). Accordingly, achieving optimal crop load for each variety is essential for vine growth and development and thus for grape production.

In this study, there was no observed change in the quality of the grapes in the both varieties: Merlot and Vranac, regarding to the crop loads. These results are inconsistent with most other studies (Petri and Clingeleffer, 2006; Reynolds et al., 2007; Brighenti et al., 2017; Drenjančević et al., 2017). Khamis et al. (2017) noted the grape quality parameters have inverse correlation with the number of buds per vine, that is, the lower crop loads increase the total soluble solids and phenolic content. Positive correlation between lower crop load levels and total soluble solids or phenolic contents in grape has been reported in many other studies (Peña-Neira et al., 2007; Gil-Muñoz et al., 2009; Bubola et al., 2011). However, some of the studies failed to find an association between crop removal treatment and some of the above-mentioned grape quality parameters (Karoglan et al., 2014; Mawdsley et al., 2018). In our study, there is no evidence that lower crop load level increases total soluble solids, total phenolics and total flavonoids in grape berries. Unfortunately, the drawback of the present study is that only two crop load levels were used in the experiment and it is very difficult to draw conclusions from. Our hypothesis was that lower crop load level (9 buds/ vine) would significantly increase total soluble solids, total phenolics and total flavonoids in grape berries of both cultivars as compared to higher crop load level (12 buds/ vine), however, the study results did not confirm it.

The results of the present study have also shown

Table 1: Yield, total soluble solids (TSS), titratable acidity (TA), total phenolic content (TPC), total flavonoid content (TFC) and total antioxidant capacity (TAC) of 'Merlot'

\begin{tabular}{lllllll}
\hline $\begin{array}{l}\text { Crop load } \\
\text { treatments }\end{array}$ & $\begin{array}{l}\text { Yield }(\mathrm{kg} \text { per } \\
\text { vine) }\end{array}$ & TSS $\left({ }^{\circ} \mathrm{Brix}\right)$ & $\mathrm{TA}\left(\mathrm{mg} \mathrm{l}^{-1}\right)$ & $\begin{array}{l}\text { TPC }(\mathrm{mg} \mathrm{GAE} \\
\left.100 \mathrm{~g}^{-1} \mathrm{FM}\right)\end{array}$ & $\begin{array}{l}\text { TFC }(\mathrm{mg} \mathrm{CE} 100 \\
\left.\mathrm{g}^{-1} \mathrm{FM}\right)\end{array}$ & $\begin{array}{l}\text { TAC }\left(\mathrm{mmol} \mathrm{Fe}{ }^{2+}\right. \\
\left.100 \mathrm{~g}^{-1} \mathrm{FM}\right)\end{array}$ \\
\hline 9 buds/vine & $3.32 \pm 0.51$ & $20.83 \pm 0.8$ & $7.14 \pm 0.06$ & $147.4 \pm 9.1$ & $80.7 \pm 7.3$ & $2.10 \pm 0.21$ \\
12 buds/vine & $3.57 \pm 0.76$ & $21.30 \pm 1.2$ & $7.16 \pm 0.04$ & $154.2 \pm 9.7$ & $84.3 \pm 5.1$ & $2.27 \pm 0.37$ \\
\hline
\end{tabular}

Values expressed as an average \pm standard deviation

Table 2: Yield, total soluble solids (TSS), titratable acidity (TA), total phenolic content (TPC), total flavonoid content and total antioxidant capacity (TAC) of 'Vranac'

\begin{tabular}{|c|c|c|c|c|c|c|}
\hline $\begin{array}{l}\text { Crop load } \\
\text { treatments }\end{array}$ & $\begin{array}{l}\text { Yield (kg per } \\
\text { vine) }\end{array}$ & TSS ( ${ }^{\circ}$ Brix $)$ & TA $\left(\mathrm{mg} \mathrm{l}^{-1}\right)$ & $\begin{array}{l}\text { TPC (mg GAE } \\
\left.100 \mathrm{~g}^{-1} \mathrm{FM}\right)\end{array}$ & $\begin{array}{l}\text { TFC (mg CE } 100 \\
\left.\mathrm{~g}^{-1} \mathrm{FM}\right)\end{array}$ & $\begin{array}{l}\text { TAC }\left(\mathrm{mmol} \mathrm{Fe} \mathrm{F}^{2+}\right. \\
\left.100 \mathrm{~g}^{-1} \mathrm{FM}\right)\end{array}$ \\
\hline 9 buds/vine & $3.32 \pm 0.44 b$ & $22.13 \pm 1.1$ & $7.07 \pm 0.11$ & $166.8 \pm 14.1$ & $75.3 \pm 6.3$ & $2.26 \pm 0.33$ \\
\hline 12 buds/vine & $4.18 \pm 0.53 a$ & $21.80 \pm 0.9$ & $7.16 \pm 0.14$ & $154.1 \pm 19.6$ & $74.3 \pm 8.1$ & $2.08 \pm 0.29$ \\
\hline
\end{tabular}

Values expressed as an average \pm standard deviation.

Different letters in each column represent significant difference among variants 
Table 3: Pearson's correlation coefficient between total phenolics (TPC)/total flavonoids (TFC) contents and total antioxidant capacity (TAC)

\begin{tabular}{llllc}
\hline & \multicolumn{2}{c}{ Merlot } & \multicolumn{2}{c}{ Vranac } \\
\hline & 9 buds/vine & 12 buds/vine & 9 buds/vine & 12 buds/vine \\
TPC vs. TAC & 0.935 & 0.922 & 0.911 & 0.915 \\
TFC vs. TAC & 0.944 & 0.951 & 0.932 & 0.926 \\
\hline
\end{tabular}

that the total soluble solids, titratable acidity and total phenolics of grape berries fell within the range expected for 'Vranac' and 'Merlot'. For example, in the study conducted by Mitić et al. (2012) total phenolics in grape of 'Vranac' and 'Merlot' were 158.6 \pm 1.9 and $169.2 \pm 2.7$ mg GAE $100 \mathrm{~g}^{-1} \mathrm{FM}$, respectively. However, numerous studies reported much higher contents of total phenolics in berries of 'Vranac' and 'Merlot' than those determined in the present research (Pajović et al., 2014; Franco-Bañuelos et al., 2017). Scientists generally agree that total phenolic contents as well as other grape quality parameters depends on many factors such as cultivar, viticulture practices and environmental conditions in the vine-growing regions. Toscano et al. (2019) reported that sub-optimal environmental conditions can influence the biosynthesis and accumulation of many secondary metabolites in plants, including phenolic compounds.

The results of this study also showed a positive correlation between total phenolics / flavonoids and total antioxidant capacity of grape berries in both varieties, regardless of crop loads applied (Table 3). Similar correlations were also determined in other published studies (Garrido et al., 2016; Cosme et al., 2018).

These results suggest that the phenolic compounds are carriers of antioxidant activity in the plant, and this hypothesis has, in fact, been confirmed by many scientists (Borges et al., 2010; Stanković et al., 2012; Balea et al., 2018).

\section{CONCLUSIONS}

Higher crop load level (12 buds/vine) as compared to lower crop load level (9 buds/vine) within the LenzMoser bilateral cordon system showed potential for increasing grape yield only for 'Merlot' under experimental conditions. However, the quality grape parameters of 'Merlot' and 'Vranac' were not influenced significantly by crop loads. Unfortunately, this study has some limitations, which have to be pointed out. The main limitation of the present study is (1) one year was included in the study and (2) small differences among crop load treatments. Therefore, further investigations involving more crop load treatments should be done to confirm the conclusions of this study.

\section{LITERATURE}

Aipperspach, A., Hammond, J., Hatterman-Valenti, H. (2020). Utilizing pruning and leaf removal to optimize ripening of Vitis riparia-based 'Frontenac Gris' and 'Marquette' wine grapes in the Northern great plains. Horticulturae, 6(1), 18. https://dx.doi.org/10.3390/horticulturae6010018

AOAC, (2000). Acidity (Titratable) of fruit products (Method No. 942.15). Retrieved from http://www.eoma.aoac.org/ methods/

Balea, Ş. S., Pârvu, A. E., Pop, N., Marín, F. Z., Pârvu, M. (2018). Polyphenolic compounds, antioxidant, and cardioprotective effects of pomace extracts from Fetească Neagră cultivar. Oxidative Medicine and Cellular Longevity, 2018, 8194721. http://dx.doi.org/10.1016/j.pathophys.2018.07.026

Benzie, I. F., Strain J. J. (1996). Ferric reducing ability of plasma (FRAP) as a measure of antioxidant power: The FRAP assay. Analytical Biochemistry, 239(1), 70-76. http://dx.doi. org/10.1006/abio.1996.0292

Bogičević, M., Maras, V., Mugoša, M., Kodžulović, V., Raičević, J., Šućur, S., Failla, O. (2015). The effects of early leaf removal and cluster thinning treatments on berry growth and grape composition in cultivars Vranac and Cabernet Sauvignon. Chemical and Biological Technologies in Agriculture, 2, 13. http://dx.doi.org/10.1186/s40538-015-0037-1

Borges, G., Degeneve, A., Mullen, W., Crozier, A. (2010). Identification of flavonoid and phenolic antioxidants in black currants, blueberries, raspberries, red currants, and cranberries. Journal of Agricultural and Food Chemistry, 58(7), 3901-3909. http://dx.doi.org/10.1021/jf902263n

Brighenti, A. F., Cipriani, R., Malinovski, L. I., Vanderlinde, G., Allebrandt, R., Feldberg, N. P., Silva, A. L. (2017). Ecophysiology of three Italian cultivars subjected to two pruning methods in Santa Catarina, Brazil. Acta Horticulturae, 1157, 381-388. http://dx.doi.org/10.17660/ActaHortic.2017.1157.53

Bubola, M., Peršurić, Đ., Kovačević Ganić, K. (2011). Impact of cluster thinning on productive characteristics and wine phenolic composition of 'Merlot'. Journal of Food Agriculture and Environment, 9(1), 36-39.

Canals, R., Llaudy, M. C. Valls, J., Canals, J. M., Zamora F. (2005). Influence of ethanol concentration on the extraction of color and phenolic compounds from the skin and seeds of 'Tempranillo' grapes at different stages of ripening. 
Journal of Agricultural and Food Chemistry, 53(10), 40194025. https://dx.doi.org/10.1021/jf047872v

Collins, C., Wang, X., Lesefko, S., De Bei, R., Fuentes, S. (2020). Effects of canopy management practices on grapevine bud fruitfulness. OENO One, 54(2), 313-325. https://dx.doi. org/10.20870/oeno-one.2020.54.2.3016

Cosme, F., Pinto, T., Vilela, A. (2018). Phenolic compounds and antioxidant activity in grape juices: A chemical and sensory view. Beverages, 4, 22. https://dx.doi.org/10.3390/beverages 4010022

Čuš, F. (2004). Influence of crop load on yield and grape quality of 'Chardonnay'. Acta Agriculturae Slovenica, 83(1), 73-83.

Drenjančević, M., Jukić, V., Zmaić, K., Kujundžić, T., Rastija, V. (2017). Effects of early leaf removal on grape yield, chemical characteristics, and antioxidant activity of grape variety Cabernet Sauvignon and wine from eastern Croatia. Acta Agriculturae Scandinavica, Section B - Soil \& Plant Science, 67(8), 705-711. http://dx.doi.org/10.1080/09064710.2017.1 332238

Franco-Bañuelos, A., Contreras-Martínez, C., S., CarranzaTéllez, J., Carranza-Concha, J. (2017). Total phenolic content and antioxidant capacity of non-native wine grapes grown in Zacatecas, Mexico. Agrociencia, 51(6), 661-671.

Gangjee, D. (2012). The Appellation of Origin in France. In Relocating the Law of Geographical Indications, (pp. 77-126). Cambridge: Cambridge University Press. http://dx.doi. org/10.1017/CBO9781139030939.005

Garrido, I., Uriarte, D., Hernández, M., Llerena, J. L., Valdés, M. E., Espinosa, F. (2016). The evolution of total phenolic compounds and antioxidant activities during ripening of grapes (Vitis vinifera 'Tempranillo') grown in semiarid region: Effects of cluster thinning and water deficit. International Journal of Molecular Sciences, 17(11), 1923. https://dx.doi. org/10.3390/ijms17111923

Gil-Muñoz, R. R., Vila-Lopez, J. I., Fernandez, J. I., MartinezCutillas, A. (2009). Effects of cluster thinning on anthocyanin extractability and chromatic parameters of 'Syrah' and 'Tempranillo' grapes and wines. OENO One, 43, 45-53. http://dx.doi.org/10.20870/oeno-one.2009.43.1.786

International Organization for Standardization. (2003). Fruit and vegetable products: Determination of soluble solids, Refractometric method (ISO Standard No. 2173). Retrieved from https://www.iso.org/standard/35851.html

Karoglan, M., Osrečak, M., Maslov Bandić, L., Kozina, B. Effect of cluster and berry thinning on 'Merlot' and 'Cabernet Sauvignon' wines composition. Czech Journal of Food Sciences, 32(5), 470-476. http://dx.doi.org/10.17221/598/2013-CJFS

Keller, M. (2010). The Science of Grapevines. London: Elsevier, Academic Press.

Khamis, M. A., Atawia, A. A. R., El-Badawy, H. E. M., Abd ElSamea, A. A. M. (2017). Effect of buds load on growth, yield and fruit quality of superior grapevines. Middle East Journal of Agriculture Research, 6(1), 152-160.

Mawdsley, P. F. W., Dodson Peterson, J. C., Casassa, L. F. (2018). Agronomical and chemical effects of the timing of cluster thinning on 'Pinot Noir' (Clone 115) grapes and wines. Fermentation, 4(3), 60. https://dx.doi.org/10.3390/fermentation 4030060

Mitić, M., Souquet, J-M., Obradović, M., Mitić, S. (2012). Phy- tochemical profiles and antioxidant activities of Serbian table and wine grapes. Food Science and Biotechnology, 21, 1619-1626. http://dx.doi.org/10.1007/s10068-012-0215-x

Ough C. S., Amerine M. A. (1988). Methods for analysis of must and wines. New York, NY: John Wiley \& Sons.

Pachnowska, K.., Ochmian, I. (2018). Cane pruning intensity of vine as a substantial factor influencing physico-chemical attributes of berries cultivar 'Regent'. Folia Pomeranae Universitatis Technologiae Stetinensis Agricultura, Alimentaria, Piscaria et Zootechnica, 343, 43-54. http://dx.doi. org/10.21005/AAPZ2018.47.3.04

Pajović, R., Raičević, D., Popović, T., Sivilotti, P., Lisjak, K., Vanzo, A. (2014). Polyphenolic characterisation of 'Vranac', 'Kratosija' and 'Cabernet Sauvignon' (Vitis vinifera L.) grapes and wines from different vineyard locations in Montenegro. South African Journal for Enology and Viticulture, 35(1), 139-148. http://dx.doi.org/10.21548/35-1-994

Pellegrino, A., Clingeleffer, P., Cooley, N. E., Walker, R. (2014). Management practices impact vine carbohydrate status to a greater extent than vine productivity. Frontiers in Plant Science 5, 283. http://dx.doi.org/10.3389/fpls.2014.00283

Peña-Neira, A., Cáceres, A., Pastenes, C. (2007). Low molecular weight phenolic and anthocyanin composition of grape skins from 'Syrah' (Vitis vinifera L.) in the Maipo valley (Chile): Effect of clusters thinning and vineyard yield. Food Science and Technology International, 13, 153-158. http:// dx.doi.org/10.1177/1082013207077920

Peppi, M. C., Kania, E., Talep, R., Castro, P., Reginato, G. (2017). Effect of different cutting heights of mechanically pruned grapevines 'Merlot' over three consecutive seasons. South African Journal of Enology \& Viticulture, 38(2), 221-227. http://dx.doi.org/10.21548/38-2-1609

Petri, P. R., Clingeleffer P. R. (2006). Crop thinning (hand versus mechanical), grape maturity and anthocyanin concentration: Outcomes from irrigated 'Cabernet Sauvignon' (Vitis vinifera L.) in a warm climate. Australian Journal of Grape and Wine Research, 12, 21-29. http://dx.doi. org/10.1111/j.1755-0238.2006.tb00040.x

Qiu, Z., Chen, G., Qiu, D. (2019). Pruning and dormancy breaking make two sustainable grape-cropping productions in a protected environment possible without overlap in a single year. PeerJ. 7, e7412. http://dx.doi.org/10.7717/peerj.7412

Raj Kumar, A., Parthiban, S., Subbiah, A., Sangeetha, V. (2017). Effect of severity of pruning on yield and quality characters of grapes (Vitis vinifera L.): A review. International Journal of Current Microbiology and Applied Sciences, 6(4), 818-835. https://dx.doi.org/10.20546/ijcmas.2017.604.103

Renouf, V., Trégoat, O., Roby, J-P., van Leeuwen, C. (2010). Soils, rootstocks and grapevine varieties in prestigious Bordeaux vineyards and their impact on yield and quality. OENO One, 44(3), 127-134. http://dx.doi.org/10.20870/ oeno-one.2010.44.3.1471

Reynolds, A. G., Schlosser, J., Sorokowsky, D., Roberts, R., Willwerth, J., de Savigny, C. (2007). Magnitude of viticultural and enological effects. II. Relative impacts of cluster thinning and yeast strain on composition and sensory attributes of 'Chardonnay Musqué. American Journal of Enology and Viticulture, 58, 25-41.

Rubio, J. A., Yuste J. (2002). Effects of cluster-thinning and the 
water regime in the yield, development, must and physiological behavior of 'Tempranillo' driven in a trellis. Viticultura y Enología Profesional, 83, 82-92.

Schamel, G. H., Schubert, G. H. (2016). An optimal control model of crop thinning in viticulture. BIO Web of Conferences 7, 03022. https://dx.doi.org/10.1051/bioconf/20160703022

Sharma, A., Shahzad, B., Rehman, A., Bhardwaj, R., Landi, M., Zheng, B. (2019). Response of phenylpropanoid pathway and the role of polyphenols in plants under abiotic stress. Molecules, 24(13), 2452. http://dx.doi.org/10.3390/molecules 24132452

Stanković, M. S., Niciforović, N., Mihailović, V., Topuzović, M., Solujić, S. (2012). Antioxidant activity, total phenolic content and flavonoid concentrations of different plant parts of Teucrium polium L. subsp. polium. Acta Societatis Botani- corum Poloniae, 81(2), 117-122. http://dx.doi.org/10.5586/ asbp. 2012.010

Šuković, D., Knežević, B., Gašić, U., Sredojević, M., Ćirić, I., Todić, S., Mutić, J., Tešić, Ž. (2020). Phenolic profiles of leaves, grapes and wine of grapevine variety Vranac (Vitis vinifera L.) from Montenegro. Foods, 9(2), 138. https://doi. org/10.3390/foods 9020138

Toscano, S., Trivellini, A., Cocetta, G., Bulgari, R., Francini, A., Romano, D., Ferrante, A. (2019). Effect of preharvest abiotic stresses on the accumulation of bioactive compounds in horticultural produce. Frontiers in plant science, 10, 1212. https://dx.doi.org/10.3389/fpls.2019.01212

Zhishen, J., Mengcheng, T., Jianming, W. (1999). The determination of flavonoid contents in mulberry and their scavenging effects on superoxide radicals. Food Chemistry, 64, 555559. http://dx.doi.org/10.1016/S0308-8146(98)00102-2 